\title{
First records of introduced carps (Teleostei, Cyprinidae) in the natural habitats of Mirim and Patos Lagoon estuary, Rio Grande do Sul, Brazil
}

\author{
Alexandre M. Garcia, Daniel Loebmann, João P. Vieira \& Marlise A. Bemvenuti \\ ${ }^{1}$ Programa de Pós-graduação em Oceanografia Biológica, Departamento de Oceanografia, Fundação Universidade Federal de \\ Rio Grande. Caixa Postal 474, 96201-900 Rio Grande, Rio Grande do Sul, Brasil. E-mail:amgarcia@mikrus.com.br
}

\begin{abstract}
This is the first record in the wild of occurrence of four carp species (bighead Aristichthys nobilis (Richardson, 1845), common Cyprinus carpio carpio Linnaeus, 1758, silver Hypophthalmichthys molitrix (Valenciennes, 1844), and grass carp Ctenopharyngodon idellus (Valenciennes, 1844)) in the Mirim Lagoon and Patos Lagoon estuary. Our findings reinforce the hypothesis that during periods of elevated rainfall and freshwater discharge, exotic species could be easily transported from overflowed ponds and lakes into the Mirim-Patos Lagoon and then estuarine area.
\end{abstract}

KEY WORDS. Exotic species, native fishes, rice-field aquaculture, sport fish ponds.

RESUMO. Este trabalho registra a ocorrência de quatro espécies de carpas (cabeça-grande Aristichthys nobilis (Richardson, 1845), comum Cyprinus carpio carpio Linnaeus, 1758, prateada Hypophthalmichthys molitrix (Valenciennes, 1844), e capim Ctenopharyngodon idellus (Valenciennes, 1844)) em ambientes naturais da Lagoa Mirim e do estuário da Lagoa dos Patos. Os resultados reforçam a hipótese de que durante períodos de excesso de chuvas e elevada descarga continental, espécies exóticas poderiam ser facilmente transportadas de tanques de cultivos e lagos transbordados para a Lagoa Mirim e a região estuarina da Lagoa dos Patos.

PALAVRAS CHAVE. Espécies exóticas, espécies nativas, pesque-pague, rizipsicultura.

\begin{abstract}
Carps are fishes from Eurasia and China that have been widely introduced around the world for aquaculture and weed control purposes (Welcomme 1988). Although carps were first introduced in Brazil in the nineteenth century, they were introduced in large numbers only in the early 1970's (Agostinho \& Julio 1996). According to Poli et al. (2000), four species have been cultivated in the Rio Grande do Sul state in southern Brazil: the bighead Aristichthys nobilis (Richardson, 1845), grass carp Ctenopharyngodon idellus (Valenciennes, 1844), common carp Cyprinus carpio carpio Linnaeus, 1758, and the silver carp Hypophthalmichthys molitrix (Valenciennes, 1844). These exotic species have been cultivated in ponds scattered around the Patos Lagoon's drainage basin, and polyculture of carps in rice-field seemed to be increasing in number along this region (Сотвім 1998), particularly at the Mirim Lagoon area.

Since 1998 we have record the occurrence of carp species in the wild at Rio Grande do Sul (Fig. 1), which were captured by artisanal fishers or during our monthly shallow-waters monitoring sampling. All collected specimens were identified and preserved in the Ichthyological Collection of the Federal Rio Grande University (FURG). Our first record was a common
\end{abstract}

carp (25 cm total length TL; 3.302 g) captured during a field survey at the Mirim Lagoon in February 1998. One year later, an adult bighead carp (105 cm total length, TL; $14.750 \mathrm{~g}$ ) was caught by artisanal fishers at the estuarine area of Patos Lagoon. In May 2001, an adult silver carp ( $88 \mathrm{~cm}$ TL; $8.900 \mathrm{~g}$ ) was caught at the estuarine area also by artisanal fishers. Recently (May 2003), a fourth species, an adult grass carp (99 cm TL; $10.570 \mathrm{~g}$ ) was found dead at the surf-zone of the adjacent marine coastal area close to the estuary's mouth. With the exception of the bighead carp specimen that was not dissected, all specimens had no distinguishable food items in their stomachs. Considering that there is no sampling effort in this region designed to document the occurrence of large exotic species, we believe that the low number of individuals reported here probably underestimates the abundance of carps in those areas.

It seems likely that these exotic fishes have escaped from overflowed ponds and lakes into the lagoon and estuarine area. Recent studies have provided increasing evidence supporting this hypothesis. Garcia et al. (2003) showed that freshwater fishes inhabiting the northern reaches of Patos Lagoon and its tributaries are carried into the lower reaches of the 


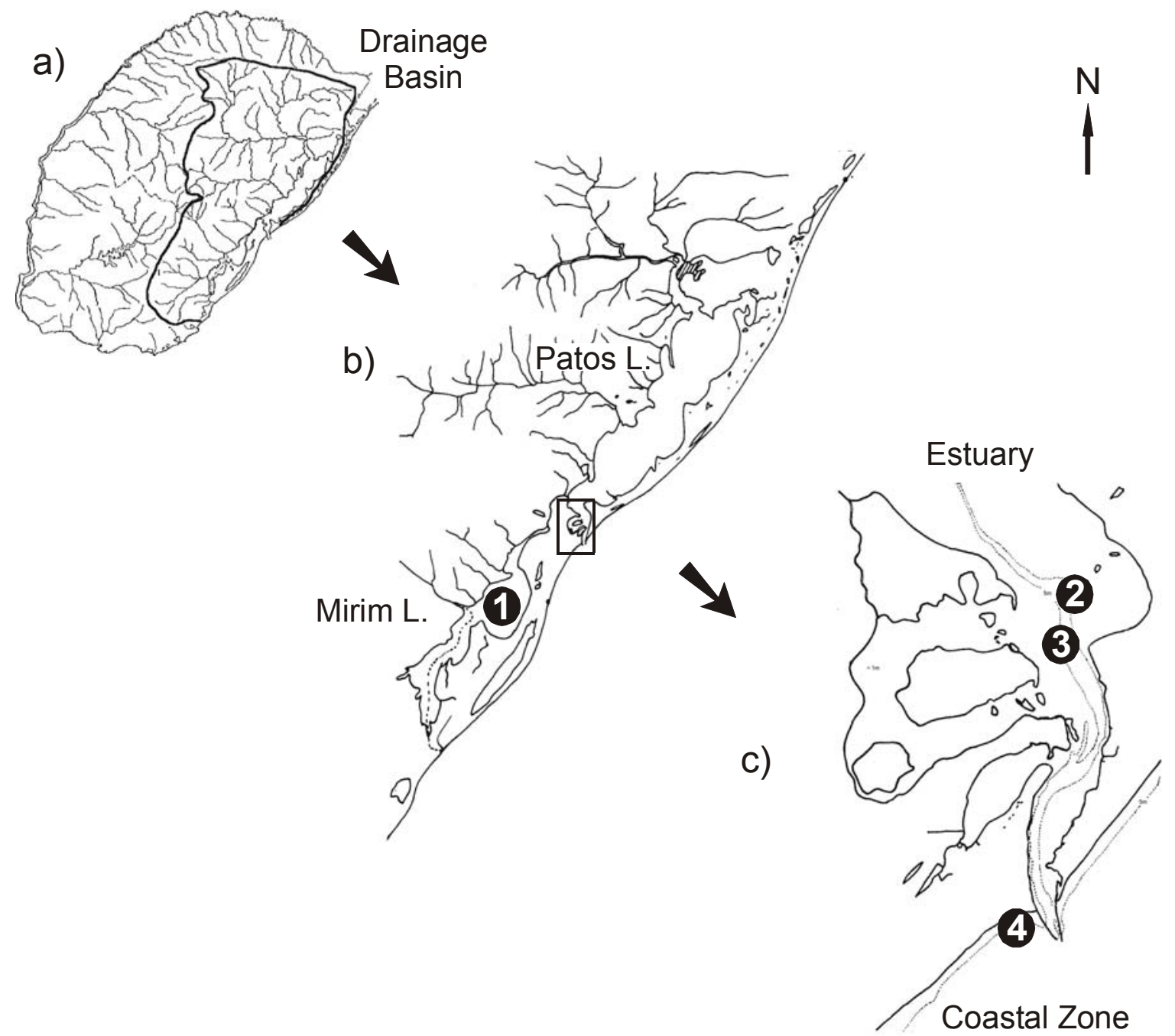

Figure 1. (a) Rio Grande do Sul state (South Brazil) showing the drainage basin of the Mirim-Patos Lagoon system (solid line); (b) Mirim and Patos Lagoon showing the main tributaries; and (c) estuarine zone of Patos Lagoon. Symbols show the locations where introduced carps were caught: (1) common carp Cyprinus carpio carpio, (2) bighead Aristichthys nobilis, (3) silver carp Hypophthalmichthys molitrix; and (4) grass carp Ctenopharyngodon idellus. The locations 2 and 3 were reported by artisanal fishers.

lagoon, and even the adjacent marine coastal area, during periods of elevated rainfall and high freshwater discharge.

Several studies elsewhere have documented the escape of introduced carps from aquaculture into natural habitats (see NAYLor et al. 2001 for further references), including some cases in southeastern Brazil (Agostinho \& JUlio 1996, Orsi \& Agostinho 1999). Silver and bighead carps, which have already established as reproducing populations elsewhere, have been associated with the following threats to native fish communities: (a) they are powerful filter-feeders and they have the potential to out-compete native filter-feeder fishes (b) they consume a broad food spectrum, and can reduce zooplankton abundance, (c) they are fast growing and can reproduce quickly (XIE \& CHen 2001). Grass carp can have negative effects on native fauna because they remove vegetation from habitats where many organisms find food resources, shelter, and spawning substrates (BAIN 1993).

The establishment of breeding carp populations in the Mirim-Patos Lagoon is a viable hypothesis. This large aquatic system has a diverse fish fauna, including several species of commercial value that support important artisanal and industrial fisheries (Сhao et al. 1985, Malabarba 1989, Vieira \& CASTELLO 1996). During their young stages many of these fishes are associated with vegetated habitats, such as seagrass mead-

Revista Brasileira de Zoologia 21 (1): 157-159, março 2004 
ows and salt marshes, which are widespread along the area of the Mirim-Patos Lagoon. Seagrass meadows, for example, play an important role as nursery grounds for commercial shrimps and coastal fishes (Garcia et al. 1996, Garcia \& Vieira 1997).

There is no evidence, however, that introduce carps have already established breeding population in the Mirim-Patos Lagoon. In fact, these fishes seemed to have strict breeding requirements that are lacking in most of the waters into which it has been introduced (Welcomme 1988). In their natural habitats in China, silver and bighead carp require long rivers for successful reproduction. These carps migrate between river and lakes, and during the monsoon flood season they lay pelagic eggs, that, along with newly hatched fry, drift with the current (XIE \& CHEN 2001). Nevertheless, breeding populations have been already become established outside their native range (e.g. Mississippi River Basin - CHICK \& Pegg 2001).

Triploid carps, which are considered to be sterile, are commonly used in aquaculture. Use of triplods prevents reproduction in natural environments by individuals that escape from aquaculture ponds. Nevertheless, techniques used to induce triploidy are not always effective, and every individual needs to be genetically screened. In the United States all carp released for vegetation control in lakes are required to be triplod. Nonetheless, carp have escaped, reproduced in the wild, and spread throughout the Mississippi Basin (NAYlor et al. 2001). The feasibility of the use of triplod carps to prevent an eventual reproduction in natural environments of the Rio Grande do Sul should be considered by the decision makers.

Carps cultivated in rice-fields and ponds can be a significant source of income for agriculture and fishing sectors in Rio Grande do Sul. Polyculture of carps in rice-fields is considered "environmentally friendly" because it generally improves soil fertility (Сотвім 1998). Yet decision makers regulating such activities should also take in account the risks and potential long-term effects of non-indigenous fishes on native fauna and ecosystems.

\section{ACKNOWLEDGEMENTS}

The study received financial support from the Conselho Nacional de Desenvolvimento Científico e Tecnológico - CNPq (Brazil).

\section{REFERENCES}

Agostinho, A.A. \& H.F. Júlio Jr. 1996. Peixes de outras águas. Ciência Hoje, Rio de Janeiro, 21: 36-44.

BaIN, M.B. 1993. Assessing impacts of introduced aquatic species: grass carp in large systems. Environmental Management, Toronto, 17: 211-224.

Chao, L.H., L.E. Pereira \& J.P. VieIRa. 1985. Estuarine fish commu- nity of the dos Patos Lagoon, Brazil. A baseline study, p. 429-450. In: A. Yanez-Arancibia (Ed.) Fish Community Ecology in Estuaries and Coastal Lagoons: Towards an Ecoystem Integration. Mexico, UNAM Press.

Chick, J.H. \& M. A. Pegg. 2001. Invasive carp in the Mississippi river basin. Science, Washington, 292: 2250-2251.

Cotrim, D. 1998. Manual prático de psicultura. EMATER, Porto Alegre. 38p.

Garcia, A.M. \& J.P. Vieira. 1997. Abundância e diversidade da assembléia de peixes dentro e fora de uma pradaria de Ruppia maritima L., no estuário da Lagoa dos Patos (RS-Brasil). Atlântica, Rio Grande, 19: 161-181.

Garcia, A.M., J.P. Vieira; C.E. Bemvenuti \& R.M. Geraldi. 1996. Abundância e diversidade da assembléia de crustáceos decapodes dentro e fora de uma pradaria de Ruppia maritima L., no estuário da Lagoa dos Patos (RS-Brasil). Nauplius, Rio Grande, 4: 113-128.

Garcia, A.M.; M.B. Raseira; J.P. Vieira; K.O. Winemiller \& A.M. GRIMM. 2003. Spatiotemporal variation in shallow-water freshwater fish distribution and abundance in a large subtropical coastal lagoon. Environmental Biology of Fishes, Netherlands, 68: 215-228.

Malabarba, L.R. 1989. Histórico sistemático e lista comentada das espécies de peixes de água doce do sistema da Laguna dos Patos, Rio Grande do sul, Brasil. Comunicações do Museu de Ciência e Tecnologia da PUCRS, Série Zoológica, Porto Alegre, 2: 107-179.

NAYlor, R.L.; S.L. Williams \& D.R. Strong. 2001. Aquaculture, a gateway for exotic species. Science, Washington, 294: 1655-1656.

Orsi, M.L. \& A.A. Agostinho. 1999. Introdução de espécies de peixes por escapes acidentais de tanques de cultivo em rios da Bacia do Rio Paraná, Brasil. Revista Brasileira de Zoologia, Curitiba, 16: 557-560.

Poli, C.R.; A. Grumann \& J.R. BorghetTI. 2000. Situação atual da aqüicultura na região sul, p. 323-352. In: W.C. VALENTI; C.R. Poli; J.A. Pereira \& J.R. Borghetti (Eds). Aquicultura no Brasil: bases para um desenvolvimento sustentável. Brasília, CNPq/MCT, 399p.

Vieira, J.P. \& J.P. Castello. 1996. Fish fauna, p. 56-61. In: U. Seeliger; C. Odebrecht \& J.P. Castello (Eds). Subtropical convergence marine ecosystem. The coast and the sea in the warm temperate southwestern atlantic. New York, Springer Verlag, 308p.

Welсомme, R.L. 1988. International introduction of inland aquatic species. Roma, Fisheries Technical Paper, vol. 294, $318 p$.

XIE, P. \& Y. Chen. 2001. Invasive carp in China's plateau lakes. Science, Washington, 294: 999-1000.

Received in 11.VI.2003; accepted in 02.III.2004. 